\title{
THE ECONOMY OF UKRAINE: DIRECTIONS OF DEVELOPMENT, NEGATIVE AND POSITIVE TRENDS
}

\author{
Maksym Pluhatyr', Lesia Patyk ${ }^{2}$ \\ National Academy of Internal Affairs, Ukraine \\ Maryna Kulyk ${ }^{3}$ \\ Educational and Scientific Institute No. 1, \\ National Academy of Internal Affairs, Ukraine
}

\begin{abstract}
The aim of the article is the analysis of the current state of Ukraine's economy, consideration of positive and negative trends and the main factors for further economic growth, as well as the definition of an effective strategy for the development of the Ukrainian economy on this basis. The subject of the study is the consideration and analysis of positive and negative trends of the Ukrainian economic development. Methodology. The research is based on the dialectical method of scientific knowledge and general scientific methods: analysis, analogy, induction, and others. At the preliminary stage of this research, scientific methods of research, such as historicallegal, logical, system-structural, comparative-legal, statistical, and others, were used. The comparative legal study of European legislation enabled to identify ways of introducing a positive foreign experience in the economic sphere. The results of the study revealed that implementing foreign experience in the national economy would be helpful in some key economic problems hindering the national economy's development. However, to integrate into the EU, Ukraine tries to overcome the negative trends of the economic crisis through reforms and adopting appropriate strategies. The main positive stages of the economic development in Ukraine over the last five years were identified. To increase the share of high-tech and innovation sector, the necessity of a current complex structural transformation of the economy was proved. Practical implications. The main principles to form and implement the economic development strategy based on the coordination of strategic priorities and strategic objectives of the EU, as well as the necessity of reforming the economic sector to develop perspective spheres of the Ukrainian economy, were determined. Relevance/originality. The coherence of strategic priorities and strategic goals to enhance the validity and effectiveness of the economic development strategy of Ukraine was proved.
\end{abstract}

Key words: economy, strategy, development, foreign experience, factors, innovation development.

JEL Classification: Q43, Q56, F63

\section{Problem statement}

The public awareness of the value of human life, importance of the full and harmonious development of each individual, his/her physical, moral, and spiritual abilities, as well as the need to create conditions for the self-realization of human potential, require of the science and executive authorities to determine the main strategies and priorities of social development of Ukraine objectively and timely. During a long period of transformation with contradictions and problems, the deep socio-economic crisis has been overcome; foundations of the market economy have been formed with the corresponding principles of social development, oriented to the principles of democracy, social and political stability in society.

At the current stage of the state, Ukraine's integration into the European Union is an essential part of the further democratization of our country, the formation of civil society (Medvedev, 2014). Therefore, over the last decade, radical socio-economic transformations have caused both positive and negative changes in modern Ukrainian society (Pavlenko, Sevruk, Kobko, 2017). An independent state is impossible without a highly effective national economy. When the independence was proclaimed, Ukraine was economically backward, characterized by a rapid decline in production and an

\footnotetext{
Corresponding author:

${ }^{1}$ Department of Administrative Law and Process, National Academy of Internal Affairs.

E-mail:mx01@ukr.net

${ }^{2}$ Department of Criminalistics and Forensic Medicine, National Academy of Internal Affairs.

${ }^{3}$ Educational and Scientific Institute No. 1, National Academy of Internal Affairs.

E-mail: coolss777@ukr.net
} 
economic crisis (Levytska, 2011). After regaining its independence in 1991, Ukraine implemented reforms aimed at an efficient market economy, but they often were inconsistent (Ekonomichnyi rozvytok). Over 27 years of Ukraine's independence, many reforms were carried out, which in most cases were ineffective and unproductive. Therefore, under current conditions, it is necessary to approach state economic growth more clearly and diplomatically, to consider past mistakes, to make a step forward in the innovation and introduction of Ukraine's economic potential in the light of the foreign experience of stabilizing the economy.

\section{Literature review}

The research of theoretical and practical aspects of the contemporary economic development of Ukraine is studied in the scientific works of M.I. Andriichuk, Z.S. Varnalii, A.A. Hretchenko, V. Daskovskyi, M.I. Zvieriakov, H. Kalachova, T.M. Kirian, V. Kysylev, E. Kyian, M. Kondratenko, N.M. Levytska, S.M.Makukha, Yu.L. Medvedev, T.I. Pavliuk, E.S. Rainert, V.V. Ruden, R. Hainberg, M.S. Shapoval. The aim of the article is the analysis of the current state of Ukraine's economy, consideration of positive and negative trends and the main factors for further economic growth and definition of an effective strategy for the development of the Ukrainian economy on this basis.

\section{The main material}

The performance of the Ukrainian economy, transformations, and processes of the past, and especially recent years affirm that the solution of problems of socioeconomic development has become strategic, global and the most important in the state. The phenomena of crisis overcoming, consequences of the global financial crisis, transition to sustainable economic growth require further elaboration of economic regulation both at the state and regional level (Ruden).

At the modern stage, a distinctive feature of the economic development is a rapid change that is characteristic of all aspects of people's life and activities. The cause of global transformations is the global economy's development under information technology development and globalization, which resulted in a new quality of the world economic space. First, this is manifested in the transformation of the world economy into a coherent global economic system because of a significant reduction in international barriers. Due to different circumstances, the rapid development and spread of innovation are the most important reason for radical changes in the global economic system. The ongoing changes cause the transformation of the goals and objectives of economic development of both developed and underdeveloped states. What the priority goals of economic development for Ukraine should be under these conditions? (Makukha, 2015).
In recent years, the Ukrainian economic development demonstrates unsustainable dynamics that confirms that its industries are at the various levels of adaptation to the challenges of the present that results in lower investment, innovation activity, and competitiveness. In addition, Ukraine is notorious as one of the most corrupt countries (Kondratenko).

Ukraine wants to become an associate member of the European Union. Accordingly, an appropriate document had been prepared for ratification at the end of November 2013 in Vilnius, but this did not happen. The ratification is postponed for an indefinite period due to the negative performance of the economy. Up to this time, the entire legislation of Ukraine has been undertaking adjustments to meet the standards of the EU member countries. Ukrainians also want to live according to these social standards, such as wages, pensions, social benefits (Kirian, Shapoval, 2014).

The globalization of society contributes to the positive interexchange of cultures, strengthening of the country's potential through adherence to the best world intellectual achievements, the study of historical experience in solving socially important issues (Sevruk, Pavlenko, 2015). It should be noted that a country that specializes in the supply of raw materials, according to the international division of labour, would inevitably come to the fact that the more it increases production, the higher the cost of production of each new unit of production (Reinert, 2011). The global economy can be perceived as a pyramid, a hierarchy of knowledge, in which those who constantly invest in innovation remain at the peak of prosperity (Reinert, 2011).

Therefore, the state policy in economic development implies the set of system measures, actions, and procedures carried out by central and local authorities to ensure effective economic reforms, aimed at improving the economic indicators and accordingly the level of social security of the population of the state. Such a policy should be implemented by certain measures, which should be carried out as a single set by state authorities.

Over the past year, the most significant positive trends achieved in Ukraine's economic development are:

1) Obtaining the fourth tranche of the IMF for $\$ 1$ billion at the beginning of April 2017. Ukraine made the necessary reforms and could replenish its gold and foreign exchange reserves, which enabled to delay the default, stabilize the macroeconomic situation and increase the trust of partners, investors, and donors in the country.

2) Eurobond placement. Due to entering the external borrowing market in September, Ukraine for the first time since 2015 has raised $\$ 3$ billion. This operation will reduce the pressure on the state budget on repayment of government debt in the coming years. This fact also indicates a partial restoration of confidence of foreign investors in Ukraine (Kyian).

3) The diversification of exports by the government to reduce the dependence of exporters on the volatility of 
traditional markets and ensure a steady flow of currency to the country. The adoption of the Export Strategy of Ukraine: Road Map for Strategic Trade Development for 2017-2021 at the end of March 2017, the full entry into force of the Association Agreement between the European Union and Ukraine from the beginning of September 2017, the Regional Convention on pan-Euro-Mediterranean preferential rules of origin, development of trade relations with Canada facilitate this trend. Negotiations on free trade agreements with Israel and Turkey are underway.

4) Relative business deregulation in 2017, especially in the construction industry, and optimization of fiscal policy, along with improvement of service of taxpayers, in particular, by the introduction of an electronic VAT refund system, significantly increased the tax base providing a surplus of state and local budgets, and contributed to a decrease in the share of shadow economy. Therefore, these improvements have had a positive influence on the investment climate and raised Ukraine up to the 76th position in the Doing Business-2018 ranking (Kyian).

It is also necessary to note the negative trends in the Ukrainian economy's development, such as:

1) Economic blockade of the ORDLO. The result was growing dependence of Ukraine on imports of energy resources, primarily coal, and a change in the ratio of capacities of various types of power plants, which excessively exceeded the permissible loads for some of them. In addition, this state of affairs influenced significantly the economic situation of enterprises that had established industrial ties with the region. At different estimates, Ukraine loses about 1\% of GDP due to the economic blockade of the ORDLO.

2) Negative trade balance. Asymmetries in foreign trade, insufficient lobbying of national interests and challenges in product certification require further reforms and capacity building to ensure Ukraine's sustainable growth (Kyian).

3) Undeveloped banking sector. In 2017, the tendency towards a reduction in the number of banks continued, which resulted in an additional burden on the Deposit Guarantee Fund, an increase in non-performing loans. In addition, access to financial resources was still limited. 4) Growing inflation. By the end of 2017, the inflation rate, according to the government's forecast, was expected to be $11.2 \%$. The reasons were the abolition of state regulation of food prices, increase of minimum wages and pensions without adequate economic growth, tendencies in household tariff increases, which led to an increase in users of subsidies by $60 \%$, a delayed decision of the NBU to raise the discount rate from $12.5 \%$ to $13.5 \%$ (Kyian).

Now Ukrainians hope to have the same level of life as people in the EU in the nearest future. But when? Here is a simple answer to this question. The analysis of the average data of GDP growth rates and average monthly wages in dollar terms in Ukraine, Russia, Poland, Germany, and the USA in the pre-crisis period of 2000-2008 can assist. Evaluations (Daskovskii, 2013) showed that with average GDP growth of $6.91 \%$ in
2000-2008, Ukraine could reach the current level of wages of the Russian Federation almost in 10 years, Poland's - in 25 years later, Germany's - in 44 years, the USA's - in 48 years (Kirian, Shapoval, 2014).

Considering such disappointing forecasts of wages, it is necessary to take radical economic decisions, first, to construct a program of socio-economic development for the medium and long-term prospects. These programs should clearly identify the priorities of economic development, year by year identifying what Ukraine will build, reconstruct, technically re-equip, and expand. Such a measure will require changes in other areas, in particular, in training professional staff with higher and secondary technical education to meet the requirements of the labour market, etc. (Kirian, Shapoval, 2014).

Special mention should go to predictive scenarios for the development of the Ukrainian economy and the macroeconomic guidelines to calculate the state budget for the next year.

The first scenario involves reforms and preservation of favourable conditions in world markets. The scenario implies a moderate reaction of the economy to reforms. According to this scenario, GDP growth will be $3 \%$ in $2019,3.8 \%$ in $2020,4.1 \%$ in 2021 . This scenario coincides with the forecasts of the IMF and, on the basis of this forecast, the Ministry of Economic Development and Trade proposes to calculate the budget for the next year (Kalachova, 2007).

The second scenario involves the implementation of complex reforms, such as land and tax reforms on taxation of corporate profits (introduction of the tax on withdrawn capital). The external environment will be favourable. According to this scenario, in 2019, GDP growth will be $4.1 \%, 5 \%$ in 2020, and $5.4 \%$ in 2021 (Kalachova, 2007).

The third scenario is pessimistic. It expects that negative trends in the external environment will weaken implementation of reforms, first, in the financial sector. The slowing of economic development and the loss of confidence of foreign investors will exacerbate Ukraine's payment for its debt obligations. According to this scenario, in 2019, GDP growth will be $1.1 \%, 1.6 \%$ in 2020, and $2.1 \%$ in 2021 (Kalachova, 2007).

The economic course of state policy is carried out in the following spheres:

- the tax and budgetary sphere, their interconnection and interdependence, planning, forecasting, and programming of the development of the state and regions; - the investment sphere in improving the investment climate in the state and promoting attraction of capital investments from abroad;

- effective allocation of productive forces at the national and regional levels;

- development of some components of the national economic complex of Ukraine (construction, transport, agro-industrial, etc.);

- development of infrastructure of the economy's sectors. 
The state economic policy is implemented by such economic regulators:

1) tax policy (local taxes' assessment, rates, privileges, and objects of taxation);

2) price policy (ensuring free pricing in market conditions and its regulation for state-defined groups of goods);

3) establishment of quotas and licensing (implementation of restrictive measures to regulate the economic activities of entities);

4) allocation of subsidies and subventions and implementation of intergovernmental transfers to balance the financial provision of the regions;

5) implementation of state procurement to standardize production activities of certain groups of economic entities and provide consumers with necessary goods (Derzhavna rehionalna polityka Ukrainy: osoblyvosti ta stratehichni priorytety).

Innovations as an important factor in improving the economic development of Ukraine and the target of the economic system of the state should be highlighted. Without innovation activation by both the state and economic entities, it is impossible to achieve domestic economic growth as a source for the welfare of the population. However, currently, the country is in dire need of innovative development, because up to now no proper conditions have been created to finance the development of science and the implementation of its achievements in production. According to Article 34 of the Law of Ukraine "On Science and Scientific-Technical Activity," the state provides scientific and scientifictechnical activities (except for defence expenditures) with the budgetary financing of at least $1.7 \%$ of Ukraine's GDP, but in fact, it is only $0.4 \%$ of GDP (Pavliuk, 2012).

Moreover, to ensure sustainable economic growth and to enter the trajectory of innovation development, Ukraine should additionally consider three main factors of further economic growth of any country in the world (Heinberg, 2013):

- depletion of essential resources, including fossil fuels and mineral resources;

- expansion of the negative impact on the environment because of both the extraction and use of resources, which leads to increased costs and complicates the efforts to counteract the negative effects;

- financial recession due to the inability (in the context of economic contraction) of the existing money, banking, and investment systems to serve the huge government and non-government debts accumulated over the past two decades.

Under current conditions of economic transition to newer technological patterns, competition in the market is complicated intensively and manifested through more complex forms. The interdependence inherent in the modern structure of "monopoly market power - oligarchy" in the Ukrainian economy should transform into a new one, "competition innovation - competitiveness - stability," which will allow determining specific fundamental changes in market-competitive relations (Andriichuk, 2018).

The series of economic crises moving one to the other forced market participants and the state to develop measures not only to ensure economic development but also to prevent a decline. It should be recognized that while the innovative tools of financial and economic growth in a stable economy are of universal (international) nature, in the context of the crisis, "recipes" of effective innovation activities are mainly individual in nature due to objective external factors and subjective internal conditions, including private features and problems (Gretchenko, 2014). Therefore, the most important task of economic development of our country for the next years should be a decisive complex structural transformation of the economy to increase the proportion of high-tech, innovation sector. Ensuring sustainable and long-term economic development requires initially forming the sector of innovative technologies, and only then integrating economically. Moreover, such integration should be with equal economies, and not with those whose level of development is much higher. In addition, the goals of economic development of Ukraine at the present stage require a mandatory state intervention to ensure domination of the industrial, science-intensive, and not the raw material and food sector (Makukha, 2015).

\section{Conclusions}

Under current conditions, the goals and objectives of Ukraine's economic development are transformed significantly, while the main problem (the task of creating an economy of catching-up modernization) not only remains but even more complicates previously unresolved socio-economic issues. Comparing the average GDP growth rates of Ukraine and the neighbouring countries (Poland, Romania, Turkey) for 2011-2014, this indicator is two-time lower in our country. To catch up with neighbours by 2030, Ukraine, according to expert estimates, should demonstrate GDP growth rates, on average, at $7 \%$ per year throughout the period. Under the current socio-economic conditions, this is unlikely (Zvieriakov, 2015). During the years of independence, the economy has been changing its structure spontaneously in favour of the raw materials industries, primary production of intermediates, and processing of materials. These industries had absorbed most of the investment, for example, metallurgy or agriculture (including grain) had a high level of liquidity in foreign markets. So gradually for Ukraine, its "resource curse" has formed (Zvieriakov, 2015). Therefore, the basis of the economic strategy of Ukraine for "European Choice" is the effective realization of deep economic, social, and political reforms, consolidation of democracy and principles of civil society (Pavlenko, Sevruk, Kobko, 2017). Consequently, to achieve high social standards, the 
Ukrainian economy needs some changes. The economic policy of Ukraine should be aimed at economic growth, an increase of incomes and quality of life in general by transforming the system of labour remuneration, diversification of the economy based on an attractive investment climate, and optimization of the tax system.

\section{References:}

Ruden V.V. Perspektyvy ta priorytety rozvytku sotsialno-ekonomichnoi systemy Ukrainy [Perspectives and Priorities of the Development of the Socio-Economic System of Ukraine] Retrieved from: http://intkonf.org/ ruden-vv-perspektivi-taprioriteti-rozvitku-sotsialno-ekonomichnoyi-sistemi-ukrayini/ (in Ukrainian)

Medvedev Yu.L. (2014). Nablyzhennia prava Ukrainy do prava Yevropeiskoho soiuzu: poniatiino-katehorialnyi aparat ta sposoby uzhodzhennia [Approximation of the law of Ukraine to the law of the European Union: Conceptual categorical apparatus and methods of harmonization]. Visnyk Luhanskoho derzhavnoho universytetu vnutrishnikh sprav imeni E.O. Didorenka [Bulletin of E. O. Didorenko Lugansk State University of Internal Affairs], 1, 52-59. (in Ukrainian)

Pavlenko S., Sevruk V., Kobko Ye. (2017). Training police officers in the conditions of reforming the system of education of the Ministry of Internal Affairs of Ukraine in accordance with European standards. Science and Education, 6, 142-150.

Levytska N.M. (2011). Istoriia Ukrainy. Ukraina v sviti: istoriia i suchasnist: navchalnyi posibnyk [History of Ukraine. Ukraine in the world: History and modernity: A teaching manual]. K.: Kondor, 418 p. (in Ukrainian)

Ekonomichnyi rozvytok [Economic Development]. USAID. Retrieved from https://www.usaid.gov/uk/ukraine/ economic-growth (in Ukrainian)

Makukha S.M. (2015, December 2). Priorytety ekonomichnoho rozvytku Ukrainy [Priorities of Economic Development of Ukraine]. Problemy rozvytku ekonomichnoi teorii v suchasnykh umovakh [Problems of economic theory development in modern conditions]. Proceedings from the XI All-Ukrainian Scientific and Practical Conference Pokrytanovski Readings. Odesa, pp. 35-39. (in Ukrainian)

Kondratenko M. Suchasnyi stan ekonomichnoi sfery v Ukraini [The current state of the economic sphere in Ukraine]. Retrieved from: https://uamodna.com/articles/suchasnyy-stan-ekonomichnoyi-sfery-v-ukrayini/ (in Ukrainian)

Kirian T.M, Shapoval M.S. (2014). Sotsialno-ekonomichnyi rozvytok Ukrainy v roky nezalezhnosti [Socioeconomic development of Ukraine in the years of independence]. Visnyk ekonomichnoi nauky Ukrainy [Bulletin of Economic Science of Ukraine], 1(25), 41-45. (in Ukrainian)

Sevruk V.H., Pavlenko S.O. (2015). Zakhody protydii transnatsionalnomu narkobiznesu, shcho vchyniaietsia predstavnykamy okremykh etnichnykh hrup [Measures to combat transnational drug trafficking committed by representatives of certain ethnic groups]. Yurydychnyi chasopys National Academy of Internal Affairs [Legal journal of National Academy of Internal Affairs], 2, 193-205. (in Ukrainian)

Reinert E.S. (2011). Kak bogatye strany stali bogatymi, i pochemu bednye strany ostaiutsia bednymi [How rich countries became rich, and why poor countries remain poor]. (N. Avtonomova Trans.). V.Avtonomov (Ed.). State University Higher School of Economics. Moscow: Publishing house of State University Higher School of Economics, 384 p. (in Russian)

Kyian Ye. Okremym nehatyvnym chynnykom, slid vidznachyty nyzku zarobitnu platu [A particular negative factor should be regarded low wages]. Retrieved from: http://icps.com.ua/ekonomichnyy-rozvytok-ukrayiny-2017dosyahnennya-nevdachi-perspektyvy/ (in Ukrainian)

Daskovskii V. (2013). Neoindustrialnoi modeli i strategii razvitiia ekonomiki [Non-industrial model and strategy of economic development]. Ekonomist [Economist], 6, 37-38. Moscow. (in Russian)

Kalachova H. (2007). Kabmin prorakhuvav stsenarii rozvytku ekonomiky na 2019-2021 roky [The Cabinet has counted the scenarios of economic development for 2019-2021 years]. Retrieved from: https://www.epravda.com.ua/ news/2018/07/11/638606/ (in Ukrainian)

Derzhavna rehionalna polityka Ukrainy: osoblyvosti ta stratehichni priorytety [State Regional Policy of Ukraine: Peculiarities and Strategic Priorities] (Monograph). Z.S. Varnalii (Eds.). K.: NISD, 820 p. (in Ukrainian)

Pavliuk T.I. (2012). Tendentsii sotsialno-ekonomichnoho rozvytku: mikro- ta makroekomichnyi aspekt [Trends in socio-economic development: Micro-and macroeconomic aspects]. Collection of science works VNAU. Ekonomichni nauky [Economic sciences], 3(69), 162-169. (in Ukrainian)

Heinberg R. (2013). Konets rosta [The end of growth]. (N. Nekrasova Trans.). Moscow: Book Club Knigovek, 384 p. (in Russian)

Andriichuk M.I. (2018). Konkurentna polityka v umovakh yevropeyskoi intehratsii Ukrainy. Naukovo-tekhnichnyi rozvytok: ekonomika, tekhnolohii, upravlinnia [Competitive policy in conditions of European integration of Ukraine. Scientific and technological development: Economy, technology, management] Proceedings from the XVII International Scientific and Practical Conference of March 28, 2018. Kyiv. K.: NTUU Ihor Sikorskyi KPI, pp. 35-36 (in Ukrainian)

Gretchenko A.A. (2014). Razvitie metodologii i sovershenstvovanie mekhanizmov formirovania natsionalnoi innovatsionnoi sistemy [Development of methodology and improvement of mechanisms for the formation of the national innovation system] (Dissertation of Doctor of Economy in specialty 08.00.05. Economy and Management of National Property (Innovation Management)). Moscow, 351 p. (in Russian)

Zvieriakov M I. (2015). Pro zminu modeli ekonomichnoho rozvytku [About the change of the model of economic development]. Ekonomika Ukrainy [Economy of Ukraine], 6(643), 41-49. (in Ukrainian) 